\title{
HUBUNGAN UMUR DAN PARITAS IBU BERSALIN DENGAN KEJADIAN PREEKLAMPSI
}

\author{
Chichi Hafifa Transyah, \\ STIKes YPAK Padang, Program Studi S-1 Keperawatan, Jl. S.Parman No 120 Padang, \\ chichitransyah@yahoo.co.id
}

Submitted: 25-10-2017 , Reviewer: 22-11-2017 , Accepted: 24-04-2018

\begin{abstract}
ABSTRAK
Angka kejadian preeklampsidi RSUP Dr. M. Djamil Padang dari tahun ke tahun terus menagami peningkatan, terutama pada tahun 2013 terjadi peningkatan yang sangat signifikan. Tujuan penelitian adalah untuk mengetahui hubungan umur dan paritas ibu bersalin dengan kejadian preeklampsi diruang kebidanan RSUP. Dr. M. Djamil Padang tahun 2015. Jenis penelitian survei analitik dengan desain cross sectional study. Penelitian ini telah dilakukan pada bulan Juli 2016. Populasi sebanyak 33 orang, semua populasi dijadikan sampel. Data diambil dari rekam medik pasien selama 15 hari.Data dianalisis secara univariat dan bivariat. Hasil penelitian didapatkan bahwa lebih dari separuh 20 orang $(60,6 \%)$ ibu hamil mengalami preeklampsi ringan, lebih dari separuh 16 orang $(48,5 \%)$ ibu hamil dengan umur tidak beresiko, lebih dari separuh 17 orang $(51,5 \%)$ ibu hamil dengan paritas tidak beresiko, dan terdapat hubungan yang bermakna antara umur dan paritas ibu bersalin dengan kejadian preeklampsi ( $\mathrm{p}$ value : 0,014 dan 0,000). Simpulan penelitian didapatkan bahwa terdapat hubungan yang bermakna antara umur dan paritas ibu bersalin dengan kejadian preeklampsi diruang kebidanan RSUP DR. M.Djamil Padang tahun 2015.
\end{abstract}

\section{Kata Kunci : Umur, Paritas, Preeklampsi}

\begin{abstract}
ABSTRCK
The incidence rate of preeclamption in Dr. M. Djamil Padang from year to year continue to menagami increase, especially in 2013 a very significant increase. The purpose of this research is to know the relationship between maternal age and parity with preoperative incident in midwifery room of RSUP. Dr. M. Djamil Padang in 2015. The research type is analytic survey with cross sectional study design. This study was conducted in July 2016. The population of 33 people, all the population sampled. Data taken from patient's medical record for 15 days. Data were analyzed univariat and bivariate. The results showed that more than half of 20 people $(60.6 \%)$ of pregnant women had mild preeclampsia, more than half of 16 people $(48.5 \%)$ of pregnant women with no risk, more than half of 17 people $(51.5 \%$ pregnant women with no risk parity, and there is a significant relationship between maternal age and parity with preeclampsia events ( $p$ value: 0,014 and 0,000 ). Conclusion of the study found that there is a significant relationship between maternal age and parity with the incidence of preeclamption in midwifery room of RSUP DR. M.Djamil Padang in 2015.
\end{abstract}

Keywords: Age, Parity, Preeklampsi 


\section{PENDAHULUAN}

Preeklampsi/eklampsi adalah timbulnya hipertensi disertai proteinuria dan edema akibat kehamilan setelah usia 20 minggu/segera setelah persalinan. Faktorfaktor predisposisi dari pre-eklampsia yaitu usia, status sosial ekonomi, genetik, komplikasi obstetrik dan kondisi medis yang sudah ada sebelumnya(JNPK-KR, 2008). Eklampsia merupakan kelanjutan dari preeklamsi berat dengan tambahan gejala kejang atau koma. Selama terjadi kejangkejang dapat terjadi suhu naik mencapai $40^{\circ} \mathrm{C}$, Frekuensi nadi bertambah cepat, dan tekanan darah meningkat (Manuaba 2010). Faktor-faktor terjadinya pre-klampsia umumnya terjadi pada kehamilan pertama kali, kehamilan diusia remaja dan kehamilan diatas diusia tua, riwayat tekanan darah tinggi yang kronis sebelum kehamilan, riwayat mengalami pre-eklampsia sebelumnya, riwayat pre-eklampsia pada ibu atau saudara perempuan, kegemukan mengandung lebih dari satu orang bayi, riwayat kencing manis, kelainan gagal ginjal (Rukiyah, A.Y. dan Yulianti, 2010).

Kejadian preeklampsia biasanya pada usia ibu yang ektrim yaitu kurang dari 20 tahun dan lebih 35 tahun keatas dan preeklampsia juga sering dijumpai pada kehamilan pada usia kehamilan 37- 42 minggu. Bila seorang ibu hamil pada usia reproduksi, kecil kemungkinan mengalami komplikasi dibanding dengan wanita hamil pada usia tua, kecil kemungkinan mengalami komplikasi di banding wanita hamil dibawah usia tua atau pun diatas usia reproduksi. Sebaiknya ibu hamil mulai umur 20-35 tahun, karena masa tersebut merupakan masa yang aman untuk hamil dimana rahim dan bagian tubuh yang lain sudah benar-benar siap untuk menerima kehamilan. Sebelum umur 25 tahun dan setelah umur 35 tahun tubuh ibu tidak sebaik pada umur 20-35 tahun (Manuaba, 2001).

Dampak preeklampsi pada ibu bersalin dengan umur $<20$ tahun dan $>35$ tahun apabila tidak dicegah akan mengakibatkan eklampsia dan bisa menambah angka kematian ibu dan bayi. Pada faktor paritas cenderung berdampak sama dengan faktor umur. Dampak pada ibu antara lain solusio plasenta, hemolisis kelainan mata, edema paru, nekrosis hati, sindroma HELLP, kelainan ginjal dan komplikasi lain. Sedangkan kematian bayi dikarenakan asfiksia intra uterin persalinan prematuritas dan kematian janin (Wiknjosastro, H, 2006).

Paritas merupakan jumlah kehamilan yang menghasilkan janin yang lahir hidup, bukan jumlah janin yang dilahirkan (Bobak, I, 2004). Paritas yang aman adalah 1-3 jumlah anak. Apabila lebih dari 3 mempunyai angka kematian lebih tinggi. Lebih tinggi paritas, lebih tinggi kematian maternal.

Resiko pada paritas tinggi dapat dikurangi atau dicegah dengan keluarga berencana (Prawirohardjo, 2002). Paritas adalah seorang wanita yang sudah pernah melahirkan bayi yang dapat hidup (Syaifuddin A ,B, 2011). Pada primipara frekuensi preeklampsia lebih tinggi bila dibandingkan dengan multipara terutama pada primipara muda. Wanita yang telah banyak melahirkan $\geq 3$ orang rentan terhadap komplikasi yang serius, bahaya pada masa kehamilan salah satunya adalah preeklampsia dimana pada paritas yang tinggi aliran darah akan menurun keplasenta yang menyebabkan ganguan plasenta sehingga terjadi gangguan pertumbuhan janin karena kekurangan oksigenasi (Prawirohardjo, 2008).

Penelitian yang dilakukan Retani, (2012) tentang hubungan antara umur dan paritas ibu bersalin dengan kejadian preeklampsia di RS Assakinah Medika Sidoarjoditemukan hasil terdapat ibu yang mengalami pre-eklampsia yang terbayak adalah umur < 20 tahun dan $>35$ tahun $(46,43 \%)$ dan pada paritas adalah primipara $(30,77 \%)$. Penelitian yang dilakukan oleh Hanum, Dkk (2013) tentang faktor resiko yang berhubungan dengan kejadian 
preeklampsia pada ibu bersalin di RSUP Dr.M.Djamil Padang di dapatkan hasil $27,7 \%$ Ibu bersalin yang mengalami pre eklampsia $83,3 \%$ terjadi pada usia berisiko $46,4 \%$ terjadi pada paritas berisiko.

Menurut WHO tahun 2010 angka kematian ibu didunia 287.000, WHO memperkirakan ada 500,000 kematian ibu melahirkan diseluruh dunia setiap tahunya, penyumbang terbesar dari angka tersebut merupakan negara berkembang yaitu $99 \%$. Perempuan meninggal akibat komplikasi selama dan setelah kehamilan dan persalinan. komplikasi utama penyumbang $80 \%$ kematian ibu adalah pre-eklampsia dan eklampsia.

Preeklampsi dan eklampsi merupakan penyebab kematian ibu di Indonesia berkisar $1,5 \%$ sampai $25 \%$, sedangkan eklamsia menyebabkan 50.000 kematian pertahun diseluruh dunia. Berdasarkan hasil survei demografi kesehatan indonesia tahun 2012, angka kematian ibu diindonesia tercatat mengalami kenaikan yang signifikan sekitar 359/100.000 kelahiran hidup. angka tersebut mengalamiKenaikan jika dibandingkan dengan SDKI tahun 2007, dimana AKI sekitar sebesar 228/100 ribu kelahiran hidup.

Jumlah Angka kematian ibu (AKI) di Sumatra Barat pada tahun 2011 akibatEklampsia 23\%, pada tahun 2012 menurun menjadi $22,9 \%$ dan pada tahun 2013 meningkat menjadi $26,2 \%$.

Survey awal yang dilakukan di Rsup Dr. M. Djamil Padang pada tanggal 8 desember 2015, didapatkan data pada tahun 2012 dengan kejadian pre-eklmpsia yaitu sebayak 158 orang, dan pada tahun 2013

\begin{tabular}{lcll}
\hline & Kejadian Pre-eklampsi & (f) & (\%) \\
\hline 1 & Berat & 13 & 39.4 \\
2 & Ringan & 20 & 60.6 \\
& Total & 33 & 100 \\
\hline
\end{tabular}

terjadi peningkatan yang signifikan terhadap kasus preeklampsia ini yaitu sebanyak 211 orang dan Pada tahun 2014 terjadi penurunan dimana kasus pre-eklampsia sebanyak 125 orang. Dan tahun 2015 sebanyak 112 orang.

Tujuan penelitian adalah untuk mengetahui hubungan umur dan paritas ibu dengan kejadian preeklampsi di RSUP Dr. M.Djamil Padang tahun 2016. Hipotesis penelitian yaitu ada hubungan umur dan paritas ibu bersalin dengan kejadian preeklampsi di RSUP Dr. M. Djamil Padang tahun 2016. Berdasarkan latar belakang diatas telah dilakukan penelitian tentang hubungan umur dan paritas ibu dengan kejadian pre-eklampsia Di RSUP Dr. M. Djamil Padang tahun 2016.

\section{METODE PENELITIAN}

Jenis penelitian ini menggunakan metode analitik dengan desaincross sectional study.Variabel dependen adalah kejadian preeklampsi dan variabel independen yaitu umur dan paritas ibu bersalin. Penelitian initelah dilakukan di ruangan kebidanan RSUP. Dr. M.Djamil Padang. Waktu pengumpulan data pada tanggal 15 sampai dengan 30 Juli 2015 dengan menggunakan lembar ceklist yang dilihat dari hasil rekam medik pasien yang mengalami kejadian preeklampsi. Populasi penelitian ini adalah seluruh ibu bersalin dengan kejadian preeklampsi diruang Kebidanan RSUP. Dr. M.Djamil Padang sebanyak 33 orang. Semua populasi dijadikan sampel. Analisis data dilakukan secara univariat untuk melihat distribusi frekuensi dari variabel dependen dan independen dan secara bivariat menggunakan uji chi square.

\section{HASIL DAN PEMBAHASAN}

\section{Kejadian Preeklampsi}

Distribusi Frekuensi ibu Bersalin

Berdasarkan Kejadian Preeklampsia

\section{Di Ruang Kebidanan RSUP. Dr. M. Djamil Padang Tahun 2016}

Berdasarkan

tabel,didapatkan

bahwa lebih dari separuh 20 orang $(60,6 \%)$ mengalami preeklampsia ringan di ruang 
kebidanan RSUP Dr. M. Djamil Padang Tahun 2016.

\section{Umur}

Distribusi Frekuensi ibu Bersalin Berdasarkan Umur Di Ruang Kebidanan Kebidanan RSUP. Dr. M. Djamil Padang Tahun 2016

\begin{tabular}{cccc}
\hline & Umur & (f) & (\%) \\
\hline 1 & Beresiko & 13 & 39.4 \\
2 & Tidak beresiko & 20 & 60.6 \\
& Total & 33 & 100 \\
\hline
\end{tabular}

Berdasarkan tabel, didapatkan bahwa lebih dari separuh 20 orang $(60,6 \%)$ umur ibu hamil tidak beresiko terhadap preeklampsia di ruang Kebidanan RSUP Dr. M. Djamil Padang Tahun 2016.

\section{Paritas}

Distribusi Frekuensi ibu Bersalin Berdasarkan Paritas Di Ruang Kebidanan RSUP. Dr. M. Djamil Padang Tahun 2016

\begin{tabular}{cccc}
\hline & Paritas & (f) & (\%) \\
\hline 1 & Beresiko & 14 & 42.4 \\
2 & Tidak beresiko & 19 & 57.6 \\
& Total & 33 & 100 \\
\hline
\end{tabular}

Berdasarkan tabel, didapatkan bahwa lebih dari separuh 19 orang $(57,6 \%)$ paritas ibu hamil tidak beresiko terhadap preeklampsia di ruang Kebidanan RSUP Dr. M. Djamil Padang Tahun 2016.

\section{Hubungan Umur dengan Kejadian Preeklampsi}

Distribusi Hubungan Umur Ibu Bersalin

Dengan Kejadian PreeklampsiaDi Ruang

Kebidanan RSUP.Dr. M.Djamil PadangTahun 2016

\begin{tabular}{|c|c|c|c|c|c|c|}
\hline \multirow{3}{*}{ Umur } & \multicolumn{4}{|c|}{ Kejadian Pre-eklampsia } & \multirow{3}{*}{$\begin{array}{c}\text { Total } \\
\mathbf{N}\end{array}$} & \multirow{3}{*}{$\%$} \\
\hline & \multicolumn{2}{|c|}{$\begin{array}{l}\text { Pre-eklampsia } \\
\text { Ringan }\end{array}$} & \multicolumn{2}{|c|}{$\begin{array}{c}\text { Pre-eklampsia } \\
\text { Berat }\end{array}$} & & \\
\hline & $\mathbf{n}$ & $\%$ & $\mathbf{n}$ & $\%$ & & \\
\hline Beresiko & 4 & 12,1 & 9 & 27,3 & 13 & $\begin{array}{c}39 \\
4\end{array}$ \\
\hline Tidak & 16 & 48,5 & 4 & 12,1 & 20 & 60 , \\
\hline
\end{tabular}

\begin{tabular}{lllllll} 
Beresiko & & & & & & 6 \\
Total & 20 & 60,6 & 3 & 39,4 & 33 & 100 \\
\hline
\end{tabular}

Berdasarkan tabel, dari 33 orang ibu hamil dengan kejadian pre-eklampsia ringan, lebih banyak pada ibu hamil dengan umur tidak beresiko $(48,5 \%)$ dibandingkan dengan ibu hamil dengan umur beresiko $(12,1 \%)$. Hasil uji statistik dengan menggunakan chisquare di dapatkan nilai $\mathrm{p}=0,014(\mathrm{p}<0,05)$, hal ini menunjukkan bahwa ada hubungan yang bermakna antara umur dengan kejadian pre-eklampsia dirungan Kebidanan RSUP Dr. M. Djamil Padang Tahun 2016.

\section{Hubungan Paritas dengan Kejadian Preeklampsi}

Distribusi Hubungan Paritas Ibu Bersalin Dengan Kejadian Preeklampsia

\begin{tabular}{|c|c|c|c|c|c|c|}
\hline \multirow{3}{*}{ Paritas } & \multicolumn{4}{|c|}{ Kejadian Pre-eklamsi } & \multirow{3}{*}{$\begin{array}{c}\text { Total } \\
\mathbf{N}\end{array}$} & \multirow{3}{*}{$\%$} \\
\hline & & $\begin{array}{l}\text { lamsi } \\
\text { an }\end{array}$ & Pre-e & amsi & & \\
\hline & $\mathbf{n}$ & $\%$ & n & $\%$ & & \\
\hline Beresiko & 3 & 9,1 & 11 & 33,3 & 14 & $\begin{array}{c}42, \\
4\end{array}$ \\
\hline $\begin{array}{l}\text { Tidak } \\
\text { Beresiko }\end{array}$ & 17 & 51,5 & 2 & 6,1 & 19 & $\begin{array}{c}57, \\
6\end{array}$ \\
\hline Total & 20 & 60 & 13 & 39,4 & 33 & $\begin{array}{c}10 \\
0\end{array}$ \\
\hline
\end{tabular}

Berdasarkan tabel, bahwa dari 33 orang ibu hamil dengan kejadian preeklamsia ringan lebih banyak pada ibu hamil dengan paritas tidak beresiko (51,5\%) dibandingkan dengan ibu hamil dengan paritas beresiko $(9,1 \%)$. Hasil uji statistik dengan menggunakan chi-square didapatkan nilai $\mathrm{p}=0,000(<0,05)$, hal ini menunjukkan bahwa ada hubungan yang bermakna antara umur dengan kejadian preeklampsia diruang Kebidanan RSUP Dr.M.Djamil Padang Tahun 2016. 


\section{PEMBAHASAN}

\section{Kejadian Preeklampsi}

Hasil penelitian yang dilakukan pada 33 orang ibu hamil, didapatkan lebih dari separuh 20 orang $(60,6 \%)$ ibu hamil yang mengalami preeklampsia ringan dan kurang dari separuh 13 orang $(39,4 \%)$ ibu hamil yang mengalami pre-eklampsia berat, di ruang Kebidanan RSUP Dr. M. Djamil Padang Tahun 2016.

Penelitian ini sama dengan penelitian yang dilakukan oleh Meriza (2010) dengan judul hubungan umur dan paritas ibu bersalin dengan kejadian preeklampsia, di RSUP Dr. M. Djamil Padang, dimana angka kejadian pre-eklampsia ringan dikategorikan tinggi yaitu 35 orang $(62,5 \%)$. Penelitian ini sama dengan penelitian yang dilakukan oleh Desi (2013) dengan judul, hubungan antara usia dengan pre-eklampsia pada ibu hami di poli KIA RSUD Kefamenanu Kabupaten Timor Tengah Utara, dimana kejadian preeklampsia ringan dikategorikan tinggi yaitu 29 orang $(83,0 \%)$.

Menurut Cuningham (2009) pre-eklampsia adalah sindroma menurunya perfungsi organ sebagai efek vasospasme dan aktivitas endotel khusus terjadi pada kehamilan setelah minggu ke-20 dimana hipertensi disertai dengan proteinuria, oedema tidak lagi dianggap sebagai kriteria diagnosa karena dapat terjadi pada wanita hamil. Untuk menegakkan dignosis preeklampsia, kenaikan tekanan sistolik harus $30 \mathrm{mmHg}$ atau lebih diatas tekanan yang biasanya ditemukan, atau mencapai 140 $\mathrm{mmHg}$ atau lebih. Kenaikan tekanan diastolik sebenarnya lebih dapat dipercaya. Apabila tekanan diastolik naik dengan 15 $\mathrm{mmHg}$ atau lebih, atau menjadi $90 \mathrm{mmHg}$ atau lebih, maka diagnosis hipertensi dapat dibuat. Pre-eklampsia digolongkan pada preeklampsia ringan dan pre-eklampsia berat.

Preeklampsi merupakan penyulit kehamilan yang akut dan dapat terjadi antenatal, intranatal dan pospartum (Prawirohardjo, 2010) pre-eklampsia juga merupakan kondisi khusus dalam kehamilan, ditandai dengan peningkatan tekanan darah (TD), bengkak pada kaki, tangan sampai mungka dan pengeluaran protein urin. Bisa berhubungan dengan kejang-kejang (Eklampsi) dan gagal organ ganda pada ibu, sementara komplikasi pada janin meliputi restriksi pertumbuhan abrosio plasenta (Capman, 2006).

Analisa peneliti bahwa lebih dari separuh terjadinya pre-eklampsia ringan ini disebabkan karna lebih banyak jumlah ibu dengan paritas $<3(57,6 \%)$ dan umur $<35$ tahun(60,6\%) dan tekanan darah $\geq 140 / 90$ mmHg. Sedangkan menurut teori (Prawiroharjo, 2010) terjadinya preeklmpasi ringan disebabkan karna menurunya perfusi organ yang berakibat terjadinya vasospasme pembuluh darah dan timbulnya hipertensi $\geq 140 / 90$ disertai edema, proteinuria $\geq 300$ mg/24 jam. Sedangkan kurang dari separuh terjadinya preeklampsia berat disebabkan karena lebih sedikit jumlah ibu dengan paritas > $3(42,4 \%)$ dan umur $>35$ tahun $(39,4 \%)$ dan tekanan darah $\geq 160 / 110 \mathrm{mmHg}$ $(39,4 \%)$. Sedangkan menurut teori (Prawirohardjo, 2010) terjadi pre-eklampsia berat disebabkan karena hipertensi dengan TD $\geq 160 \mathrm{mmHg}$ disertai proteinuria lebih 5 $\mathrm{g} / 24$ jam, produksi urin kurang dari $500 \mathrm{cc} / 24 \mathrm{jam}$, penurunan trombosit dengan cepat.

\section{Umur}

Hasil penelitian terhadap 33 orang ibu hamil didapatkan lebih dari separuh 20 Orang $(60,6 \%)$ umur ibu hamil yang tidak beresiko terhadap preeklampsia dan kurang dari separuh 13 orang $(39,4 \%)$ umur ibu hamil yang beresiko terhadap pre-eklampsia, di ruang Kebidan RSUP Dr.M. Djamil Padang Tahun 2016.

Penelitian ini sama dengan penelitian yang dilakukan oleh Yunirman (2013) dengan judul gambaran umur dan paritas ibu bersalin dengan kejadian pre-eklampsia terdapat kurang dari separuh $(39,6 \%)$ memiliki usia beresiko di RSUP Dr.M.Djamil padang 2013. Penelitian lain yang dilakukan oleh Harmonis 
(2015) dengan judul hubungan umr dan paritas dengan kejadian pre-eklampsia terdapat lebih dari separuh $(63,1 \%)$ memiliki usia beresiko terhadap pre-eklampsia di RSUD Dr. Rasyidin Padang Tahun 2015.

Usia sangat mempengaruhi kehamilan maupun persalinan. Usia yang baik untuk hamil atau melahirkan 20 sampai 35 tahun. Pada usia tersebut alat reproduksi wanita telah berkembang dan berfungsi secara maksimal. Sebaliknya pada wanita dengan usia dibawah 20 tahun atau diatas 35 tahun kurang baik untuk hamil maupun melahirkan, karena kehamilan pada usia ini memiliki resiko tinggi seperti terjadinya keguguran, atau kegagalan persalinan, bahkan bisa menyebabkan kematian. Wanita yang usianya lebih tua memiliki tingkat resiko komplikasi melahirkan lebih tinggi dibandingkan dengan yang lebih muda. Bagi wanita yang berusia 35 tahun keatas, selain fisik melemah, juga kemungkinan munculnya berbagai resiko gangguan kesehatan, seperti darah tinggi, diabetes dan berbagai penyakit lain (Gunawan S, 2010).

Menurut Manuaba (2003), usia dibawah 20 tahun bukan masa yang baik untuk hamil karena organ-organ reproduksi belum sempurna. Hal ini tentukan akan menyulitkan proses kehamilan dan persalinan. Sedangkan kehamilan diatas 35 tahun mempunyai resiko untuk mengalami komplikasi dalam kehamilan dan persalinan antara lain perdarahan, gestosis, atau hipertensi dalam kehamilan distosia dan partus lama. Terjadinya keguguran, hipertensi dalam kehamilan paling sering mengenai wanita yang lebih tua, yaitu bertambahnya usia menunjukan peningkatan insiden hipertensi kronis menghadapi resiko yang lebih besar untuk menderita hipertensi karena kehamilan. Wanita hamil dengan usia kurang dari 20 tahun insiden pre-eklampsia /eklampsia lebih dari 3 kali lipat. Pada wanita hamil berusia lebih dari 35 tahun dapat terjadi hipertensi laten oleh karena itu semakin lanjut usia maka kualitas sel telur sudah berkurang hingga berakibat kegagalan persalinan, bahkan bisa menyebabkan kematian.
Menurut analisa peneliti bahwa umur terlalu muda atau terlalu tua merupakan faktor terjadinya pre-eklampsia umur kurang dari 20 tahun sangat beresiko karna belum matangnya alat reproduksi untuk hamil, dan > 35 tahun fungsi organ reproduksi juga mulai mengalami penurunan sehingga tidak dapat bekerja secara maksimal.

Hasil penelitian terhadap 33 orang ibu hamil didapatkan lebih dari separuh 19 orang $(57,6 \%)$ paritas ibu hamil yang tidak beresiko terhadap pre-eklmpsia dan kurang dari separuh 14 orang $(42,4 \%)$ paritas ibu hamil beresiko terhadap preeklampsi diruang Kebidanan RSUP Dr. M. Djamil Padang Tahun 2016.

Penelitian ini sama dengan penelitian yang dilakukan oleh Sukriani (2013) dengan judul hubungan umur dan paritas pada ibu bersalin dengan kejadian pre-eklampsia dimana di dapatkan hasil lebih dari separuh $(51,2 \%)$ ibu memiliki paritas beresiko di RSUP Dr. M. Djamil padang tahun 2013. Penelitian ini sama dengan penelitian yang dilakukan oleh wahyuni (2014) dengan judul hubungan umur dan paritas ibu bersalin dengan kejadian pre-eklampsia dimana didapatkan hasil lebih dari separuh $(69,2 \%)$ ibu memiliki paritas beresiko dirumah sakit tingkat III Dr. Reksodiwiryo.

Keadaan seorang wanita sehubungan dengan kelahiran anak yang dapat hidup (Dorlan, W, A, 2002). Paritas yang aman adalah 1-3 jumlah anak. Apabila lebih dari 3 mempunyai angka kematian lebih tinggi. Lebih tinggi paritas, lebih tinggi kematian maternal. Resiko pada paritas tinggi dapat di kurangi atau dicegah dengan keluarga berencana ( Prawirohardjo, 2002 ).

Paritas merupakan salah satu faktor predisposisi terjadinya pre eklamsia pada primigravida frekuensi pre-eklampsia lebih tinggi dibandingkan dengan multigravidaterutama primigravida muda (Winkjosatro, 2006). Paritas dikatakan tinggi bila seorang wanita melahirkan anak ke empat atau lebih. Paritas tinggi mempunyai angka 
kematian maternal lebih tinggi. Lebih tinggi paritas, lebih tinggi pula kematian maternal.

Resiko pada paritas tinggi dapat dikurangi atau dicegah dengan keluarga berencana (Prawirohardjo, 2002). Paritas adalah seorang wanita yang sudah pernah melahirkan bayi yang dapat hidup (Syaifuddin A ,B, 2011). Pada primipara frekuensi preeklampsia lebih tinggi bila dibandingkan dengan multipara terutama pada primipara muda. Wanita yang telah banyak melahirkan $\geq 3$ orang rentan terhadap komplikasi yang serius, bahaya pada masa kehamilan salah satunya adalah preeklampsia dimana pada paritas yang tinggi aliran darah akan menurun keplasenta yang menyebabkan ganguan plasenta sehingga terjadi gangguan pertumbuhan janin karena kekurangan oksigenasi (Prawirohardjo, 2008).

Analisa peneliti bahwa paritas merupakan salah satu faktor terjadinya preeklampsi pada ibu hamil, yang disebabkan kurangnya kunjungan tenaga kesehatan ke masyarakat, kurangnya informasi pada pasangan usia subur namun tidak selalu ibu memiliki paritas 1-3 terbebas dari preeklampsi ini. Jadi baik ibu yang termasuk kedalam kelompok yang memiliki paritas tinggi ( $>3$ ) maupun rendah (1-3) untuk sama-sama memperhatikan kondisi kehamilannya karena kelompok ini sama-sama memiliki peluang yang cukup besar terjadinya preeklampsi.

\section{Hubungan umur dengan kejadian Preeklampsi}

Hasil penelitian bahwa dari 33 orang ibu hamil terdapat 13 orang $(39,4 \%)$ dengan umur beresiko terhadap pre-eklampsia dan 20 orang $(60,6 \%)$ ibu hamil yang umurnya tidak beresiko mengalami preeklampsi diruang Kebidanan Rsup Dr. M. Djamil Padang Tahun 2016.Hasil uji statistik dengan chi-square didapatkan nilai $\mathrm{p}=0,014$ ( $\mathrm{p} \leq 0,05)$, hal ini menunjukan bahwa ada hubungan yang signifikan antara umur dengan kejadian preeklampsi.

Penelitian ini sama dengan penelitian yang dilakukan oleh Saputri (2013) dengan judul faktor-faktor yang berhubungan dengan kejadian pre-eklampsia di RSUP. Dr. M. Djamil Padang, dimana di dapatkan hasil lebih dari separuh $(61,6 \%)$ umur yang beresiko dengan $p$ value $=(0,003)$ maka nilai $(p<0,05)$ terdapat hubungan yang bermakana antara umur dengan kejadian preeklampsi. Penelitian ini juga sama dengan penelitian yang dilakukan oleh Ucianita (2014) dengan judul hubungan umur dan paritas ibu bersalin dengan kejadian pre-eklampsia di RSUD Dr. Rasyidin Padang. Dimana didapatkan nilai $\mathrm{p}$ value $=(0,026)$ maka nilai $(\mathrm{p}<0,05)$ terdapat hubungan bermakna antara umur dengan kejadian preeklampsi.

Menurut teori Cuningham (2009) bahwa salah satu faktor yang menimbulkan kejadian pre-eklampsia adalah wanita yang berada pada awal atau akhir usia reproduksi karena dalam usia tersebut organ-organ reproduksi tidak berfungsi secara optimal atau ketidakmampuan untuk hamil dalam usia tua. Disini bisa kita lihat dengan meningkatnya usia terjadi pengecilan pembuluh darah sebagai akibatnya terjadinya hipertensi baik yang menyangkut tekanan diastolik maupun tekanan sistolik.

Penelitian yang dilakukan Retani, (2012) tentang hubungan antara umur dan paritas ibu bersalin dengan kejadian preeklampsia di RS Assakinah Medika Sidoarjoditemukan hasil terdapat ibu yang mengalami pre-eklampsia yang terbayak adalah umur $<20$ tahun dan $>35$ tahun $(46,43 \%)$ dan pada paritas adalah primipara $(30,77 \%)$.

Analisa peneliti bahwa dari hasil peneliti didapatkan ibu hamil dengan kejadian preeklampsi ringan, lebih banyak pada ibu hamil dengan umur tidak beresiko dibandingkan dengan ibu hamil dengan umur beresiko. Umur dapat menjadi penyebab terjadinya pre-eklampsia pada ibu hamil, usia kurang dari 20 tahun sangat beresiko karena belum matangnya alat reproduksi untuk hamil dan lebih dari 35 tahun dianggap lebih rentan terhadap terjadinya pre-eklampsia. 
Upaya yang dilakukan tempat penlitaian disarankan kejadian pre-eklampsia yang disebabkan oleh faktor umur, dapat dicegah salah satunya dengan memberikan penyuluhan dan informasi tentang pengaruh umur dengan kejadian preeklmpsia.

\section{Hubungan Paritas dengan kejadian Preeklampsi}

Berdasarkan hasil penelitian bahwa dari 33 orang ibu hamil terdapat 14 orang $(42,4 \%)$ dengan paritas beresiko terhadap preeklampsi dan 19 orang $(57,6 \%)$ ibu hamil yang paritasnya tidak beresiko yang mengalami preeklampsi di ruang Kebidanan RSUP Dr.M Djamil Padang Tahun 2016. Hasil uji statistik dengan chi-square didapatkan nilai $\mathrm{p}=0,000(\mathrm{p} \leq 0,05)$, hal ini menunjukan bahwa ada hubungan yang bermakna antara umur dengan kejadian preeklampsi.

Penelitian ini sama dengan penelitian yang dilakukan Amelia (2014) dengan judul hubungan umur dan paritas ibu bersalin dengan kejadian pre-eklampsia di RSUD Dr. Rasyidin Padang, bahwa nilai $\mathrm{p}=$ 0,004 maka $(\mathrm{p}<0,05)$ terdapat hubungan yang bermakna antara paritas dengan kejadian preeklampsi.

Penelitian ini yang dilakukan Ucintia (2014) dengan judul hubungan umur dan paritas ibu bersalin dengan kejadian preeklampsia di RSUD. Dr Rasidin Padang bahwa nilai $\mathrm{p}=0,021$ maka $(\mathrm{p}<0,05)$ terdapat hubungan yang bermakna antara paritas dengan kejadian preeklampsi.

Paritas merupakan jumlah kehamilan yang menghasilkan janin yang lahir hidup, bukan jumlah janin yang dilahirkan (bobak, I, 2004). Paritas yang aman adalah 1-3 jumlah anak. Apabila lebih dari 3 mempunyai angka kematian lebih tinggi paritas lebih tinggi kematian maternal.

Resiko pada paritas tinggi dapat dikurangi atau dicegah dengan keluarga berencana (Prawirohardjo, 2002). Paritas adalah seorang wanita yang sudah pernah melahirkan bayi yang dapat hidup
(Syaifuddin A ,B, 2011). Pada primipara frekuensi preeklampsi lebih tinggi bila dibandingkan dengan multipara terutama pada primipara muda. Wanita yang telah banyak melahirkan $\geq 3$ orang rentan terhadap komplikasi yang serius, bahaya pada masa kehamilan salah satunya adalah preeklampsi dimana pada paritas yang tinggi aliran darah akan menurun keplasenta yang menyebabkan ganguan plasenta sehingga terjadi gangguan pertumbuhan janin karena kekurangan oksigenasi (Prawirohardjo, 2008).

Analisa peneliti bahwa dari hasil penelitian yang telah didapatkan dengan kejadian preeklampsi ringan lebih banyak pada ibu hamil dengan paritas tidak beresiko dibandingkan dengan ibu hamil yang beresiko. Paritas merupakan faktor predisposisi kejadian preeklampsi yang memiliki pengaruh. Hal ini sesuai teori yang diungkapkan bahwa paritas $>3$ merupakan salah satu faktor predisposisi dari preeklampsi (Prawirohardjo, 2008).

Upaya yang dilakukan tempat penelitian diharapkan kepada ibu agar selalu melakukan antenatal care (ANC), nutrisi harian dan disarankan untuk mengikuti program keluarga berencana (KB).

\section{SIMPULAN}

Dari hasil penelitian dapat disimpulkan bahwa lebih dari separuh ibu hamil dengan kejadian pre-eklampsia ringan, lebih dari separuh ibu hamil dengan umur tidak beresiko, lebih dari separuh ibu hamil dengan paritas tidak beresiko dan terdapat hubungan yang bermakana antara umur dan paritas dengan kejadian preeklampsia Di RSUP Dr M Djamil Padang Tahun 2016.

\section{UCAPAN TERIMA KASIH}

Ucapan terima kasih kepada direktur RSUP Dr. M. Djamil Padang yang telah memberikan kesempatan kepada peneliti untuk mengadakan penelitian, dan khususnya Ruangan Kebidanan tempat peneliti melakukan penelitian sehingga terlaksana dengan baik. 


\section{DAFTAR PUSTAKA}

Bobak, I, 2004. Keperwatan Maternitas. Jakarta : EGC.

Boathamley, Judy Dan Maureen Boyle, 2012. Patofisiologi Dalam Kebidanan. Jakarta : EGC.

Chapman Vicky, 2006. Asuhan Kebidanan Persalinan Dan kelahiran. Jakarta : EGC.

Cunningham, F Gary, Dkk. 2009. Obstetri Williams Edisi 1 Dan 2. Jakarta : EGC.

Hidayati nofita, kurniawati titik 2012. Hubungan Umur Dan Paritas Dengan Kejadian Pre-Eklampsia Pada Ibu Hamil Di Puskesmas Bangetayu Kota Semarang : Akademi Kebidanan Abdi Husada. Diakses Pada Tanggal 15 September 2015.

Hanum Huda, Bd Farida 2013. Faktor Resiko Yang Berhubungan Dengan Kejadian Pre-Eklampsia Pada Ibu Bersalin Di Rsup Dr. M. Djamil Padang : Poltekes Kemenkes Jurusan Kebidan Padang. Diakses Pada Tanggal 20 0ktiber 2015.

Manuaba Ida Ayu Chadranita 2010. Ilmu Kebidanan Penyakit Kandung Dan KB. Jakarta : EGC.

Meriza, 2010. Hubungan Umur Dan Paritas Ibu Bersalin Dengan Kejadian PreEklampsia Di Rsup Dr. M.Djamil Padang : Akademi Kebinana Alifah Padang.

Mitayani, 2011. Asuhan Keperawatan Maternitas. Jakarta : Salemba Medina.

Mochtar, R, 1998. Ilmu Kebidanan Dan Kandungan. Jakarta : EGC.

Noatmojdo Soekidjo, 2012. Metedologi Penelitian Kesehatan Edisi Revisi. Jakarta : Rineka Cipta.
Nursalam Dan Pariani, S, 2001. Pendekatan Praktis Metodelogi Riset Keperawatan. Jakarta : CV. Info Medika.

Prawirohardjo, 2010. Ilmu Kebidanan. Jakarta : Yayasan Bina Pustaka.

Rukiyah Yeyeh Ai 2010. Asuhan Kebidan Patologi Kebidanan. Jakarta : Trans Info Media.

Retani Tri Indah Idi 2013. Umur Dan Paritas Ibu Bersalin Dengan Kejadian PreEklampsia Di Rs Assakinah Medika Sidoarjo : Akademi Kebidanan Griaya Husada. Diakses Pada Tanggal 20 September.

Robson, Elizabeth S Dan Jason Waugh. 2012. Patologi Pada Kehamilan. Jakarta, : EGC.

Sukriani, 2013. Hubungan Usia Dan Paritas Ibu Bersalin Dengan Kejadian PreEklampsia Di Rsup Dr. M. Djamil Padang : Akademi Kebidanan Alifah Padang.

Safutri, 2013. Faktor-Faktor Yang Berhubungan Dengan Kejadian PreEklampsia Di Rsup Dr. Djamil Padang : Akademi Kebidanan Alifah Padang.

Wahyuni Dewi, Mifbakhuddin, Sutrimah 2014. Faktor-Faktor Yang Berhubungan Dengan Kejadian Pre-Eklampsia Pada Ibu Hamil : Dirumah Sakit Roemani Muhamadiyah Semarang : Akademi Kebidanan Muhamadiyah Semarang. Diakses Pada Tanggal 1 Januari 2016.

Winkjosastro, H, 2006. Ilmu Kebidanan. Jakarta YBPSP.

Wahyuni, 2014. Hubungan Umur Dan Paritas Ibu Bersalin Dengan Kejadian PreEklampsia Dirumah Sakit Tk. III Dr. Reksodiwiryo : Akademi Kebidanan Alifah Padang.

Yogi Etika Desi, Harianto, Sonbay Elfrida 2011. Hubungan Antara Usia Dengan Pre-Eklampsia Pada Ibu Hamil Di Poli 
Kia Rsud Kefamenanu Kabupaten Timor Tengah Utara. Jurnal Delima Harapan, Vol 3 No 2, Agustus 2014. Diaksese Pada Tanggal 8 Desember 2015.

Yunirman, 2013. Gambaran Umur Dan Paritas Ibu Bersalin Dengan Kejadian Pre-Eklampsia Rsup Dr. M. Djamil Padang : Akademi Kebidanan Amanah Padang. 
e-ISSN : 2528-66510 Volume3No.1 Tahun2018:

Jurnal Human Care 